\title{
Waste Heat Recovery from Boiler of Large-Scale Textile Industry
}

\author{
${ }^{1}$ Prateep Pattanapunt, ${ }^{1}$ Kanokorn Hussaro, ${ }^{1}$ Tika Bunnakand and ${ }^{2}$ Sombat Teekasap \\ ${ }^{1}$ Rattanakosin College for Sustainable Energy and Enviroment, \\ Rajamangala University of Technology Rattanakosin, \\ Puthamonthon Sai 5, Salaya, Puthamonthon, Nakhon Pathom, 73170, Thailand \\ ${ }^{2}$ Department of Mechanical Engineering, Faculty of Engineering, \\ Eastern Asia University, Thanyaburi, Pathum Thani, 12110, Thailand
}

Received 2013-05-24, Revised 2013-06-20; Accepted 2013-06-21

\begin{abstract}
Many industrial heating processes generate waste energy in textile industry; especially exhaust gas from the boiler at the same time reducing global warming. Therefore, this article will present a study the way to recovery heat waste from boiler exhaust gas by mean of shell and tube heat exchanger. Exhaust gas from boiler dyeing process, which carries a large amount of heat, energy consumptions could be decrease by using of waste-heat recovery systems. In this study, using ANASYS simulation performs a thermodynamics analysis. An energy-based approach is performed for optimizing the effective working condition for wasteheat recovery with exhaust gas to air shell and tube heat exchanger. The variations of parameters, which affect the system performance such as, exhaust gas and air temperature, velocity and mass flow rate and moisture content is examined respectively. From this study, it was found that heat exchanger could be reduced temperature of exhaust gases and emission to atmosphere and the time payback is the fastest. The payback period was determined about 6 months for investigated ANSYS. The air is circulated in four passes from the top to the bottom of the test section, in overall counter-flow with exhaust gas. The front area is $1720 \times 1720 \mathrm{~mm}$, the flow length $7500 \mathrm{~mm}$, the inner and outer diameter of exhaust gas is $800 \mathrm{~mm}$, the tube assembly consist of 196 tubes, the tube diameter is $76.2 \mathrm{~mm}$, the tube thickness is $2.6 \mathrm{~mm}$, the tube length is $4500 \mathrm{~mm}$, the tube length of air inner and outer is $500 \mathrm{~mm}$. The result show that, the boiler for superheated type there are exhaust gas temperature is $190^{\circ} \mathrm{C}, 24 \%$ the moisture content of fuel and there are palm kernel shell 70 tons day ${ }^{-1}$ which there are the high temperature after the heat exchanger, $150^{\circ} \mathrm{C}$. It was occurred acid rain. The hot air from heat exchanger process can be reduced the moisture of palm kernel shell fuel to $15 \%$. The fuel consumption is reduced by about $2.05 \%\left(322.72 \mathrm{~kJ} \mathrm{~kg}^{-1}\right)$, while the shell and tube heat exchanger outlet exhaust gas temperature decreases from 190 to $150^{\circ} \mathrm{C}$.
\end{abstract}

Keywords: Waste Heat Recovery, Shell and Tube Heat Exchanger, Boiler, Palm Shell and Exhaust (Flue) Gas

\section{INTRODUCTION}

The Textile Industry (TI) is one of the most complicated manufacturing industries and the oldest industrial sectors in Thailand. Because it is a fragmented and heterogeneous sector dominated by Small and
Medium Enterprises (SMEs). Characterizing the textile manufacturing industry is complex because of the variety of substrates, processes, machinery and components used and finishing steps undertaken (Hasanbeigi and Price, 2012). Cotton is the primary raw material followed by synthetic yarns (rayon and nylon). The production of Technology, Rattanakosin, Puthamonthon Sai 5, Salaya, Puthamonthon, Nakhon Pathom, 73170, Thailand 
cotton yarns and fabrics involved the following general processes: Spinning (twisting/texturing), weaving (knitting/tufting/nonwoven) and wet processing which includes scouring, de-sizing, washing, mercerizing, bleaching, dyeing, printing and finishing of yarns and fabrics as shows in Fig. 1. The main products are yarns and finished fabric (Zabaniotou and Andreou, 2010).

The Textile Industry (TI) uses large quantities of both electricity and thermal (such as in boilers, motor systems, distribution). The fuels used for the production of thermal energy in general in Thailand are Diesel oil, Heavy Fuel Oil, LPG, coal, natural gas and Solid fuels (such as palm oil shell). Electricity is the major type of energy used in spinning plants, especially in cotton spinning systems. If the spinning plant just produces raw yarn in a cotton spinning system and does not dye of fix the produced yarn, the fuel may just be used to provide steam for the humidification system in the cold seasons for preheating the fibers before spinning them together (Hasanbeigi and Price, 2012).

The total amount and types of wastes have increased due to rapid industrial development in recent years. A focus on environmental problems caused by industrial wastes, especially those containing waste heat in textile industry. Considering the environmental protection and also in the context of great uncertainty over future supplies, attention is concentrated on the utilization of sustainable energy sources and the energy conservation methodologies (Pandiyarajan et al., 2011). High capacity biomass (such as palm oil shell) is one of the most widely used boiler units for Dyeing process. Nearly one-third of input energy is wasted through exhaust gas of these boilers. Decreasing energy losses and recovering the lost energy are of great importance. This waste energy in form of heat can be removed and used for other applications for environment protecting and the energy saving purpose.

In each production process of the Textile Industry (TI), the heating and cooling of gases and liquids are frequently required. This is done through heat exchange between different fluids and in order to avoid contamination or chemical reaction due to their direct contact, heat exchangers are used to carry out indirect heating and cooling. It is important to use the right heat exchanger for the intended purpose. Boiler flue gases contain substantial heat energy. This energy can be utilized to preheat the boiler feed water through economizer (Chaojun et al., 2012). It is well known that the utilization of waste heat of flue gases is of the best possibilities for reduction of the green house gases emissions. Different types of heat exchenger represents primary importance in heat recovery systems design. It is necessary to perform the design is such a way so that there were utilize conventional types of heat exchnagers with maximum degree of compactness in relation to process parameters like temperature, composition of process fluids, proximity to fouling and potential problems. The possibility to use ceramic materials which have been subject to intense development in the last 40 years and they exhibit good properties at high temperatures (up to $1400^{\circ} \mathrm{C}$ ). However, generally, these ceramic materials, if they are application for temperatures around $1000^{\circ} \mathrm{C}$, are too expensive. There were use for lower temperatures in flue gas (off-gas) application is technically possible but is economically too expensive. Therefore, most requirements for common high temperature flue gas industrial applications (up to $1000^{\circ} \mathrm{C}$ ) use metallic mateerials (Stehlik, 2011).

Pandiyarajan et al. (2011) have performed experiments on heat recovery from diesel engine exhaust using finned shell and tube exchanger and thermal storage system. Depending on the temperature level of exhaust stream and the proposed application, different heat exchange devices, heat pipes and combustion equipment's can be employed to facilitate the use of the recovered heat. The shell and tube heat exchanger is the most widely used type industrial heat transfer equipment. Initially, only plain tubes were used in shell and tube heat exchangers. The heat transfer coefficient (h) for gases is generally several times lower than that for water, oil and other liquids. In order to minimize size and weight of a gas to liquid heat exchanger, the thermal conductance (hA) on both sides of the exchanger should be approximately the same. Therefore, the heat transfer surface on the gas side needs to have a much larger area and be more compact than can be realized practically with the circular tubes commonly used in shell and tube exchangers.

The thermal design of the condensing boiler aims to estimate adequate surface area of the heat exchanger to handle the required thermal duty. Therefore, heat transfer coefficients need to be evaluated before the size of the condensing boiler can be calculated. The heat transfer coefficient (h) can be written as. 


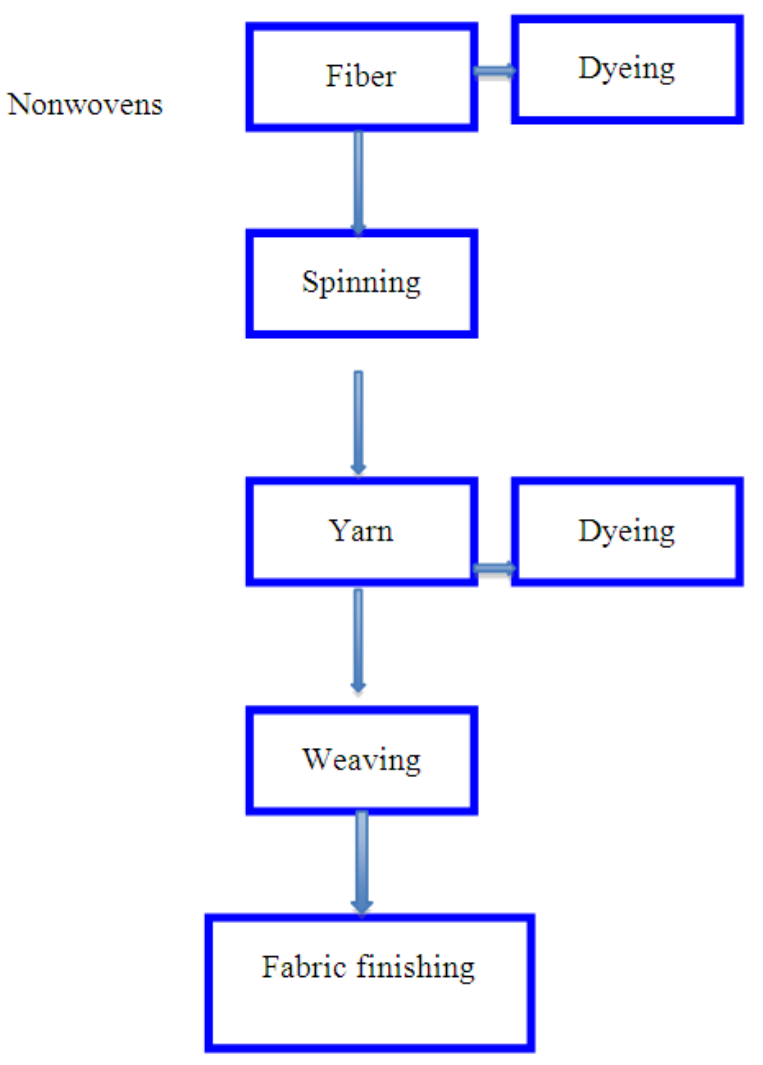

Fig. 1. The textile process

\subsection{Tube-Side Heat Transfer Coefficient}

The correlation (Nusselt number) obtained under fully developed turbulent flow in smooth tubes can be to calculate the tube-side heat transfer coefficient Equation 1 (Chen et al., 2012):

$$
\mathrm{Nu}_{\mathrm{t}}=\frac{\mathrm{h}_{\mathrm{t}} \mathrm{d}_{\mathrm{i}}}{\lambda_{\mathrm{t}}}=\frac{\left(\frac{\mathrm{f}}{2}\right)(\mathrm{Re}-1000) \operatorname{Pr}}{1+12.7\left(\frac{\mathrm{f}}{2}\right)^{\frac{1}{2}}\left(\operatorname{Pr} \frac{2}{3-1}\right)}
$$

Where:

$\lambda_{\mathrm{t}}=$ The thermal conductivity of the water on the tubeside

$\mathrm{d}_{\mathrm{i}}=$ The inner diameter of the tubes

$\mathrm{h}_{\mathrm{t}}=$ The tube-side heat transfer coefficient

$\mathrm{P}_{\mathrm{r}}=$ The Prandtl number and $\mathrm{f}$ can be expressed as Equation 2:

$$
f=(1.58 \ln R e-3.28)^{-2}
$$

For flow in a pipe or tube, the Reynolds number is generally defined as Equation 3 (Chen et al., 2012):

$$
\operatorname{Re}=\frac{p v D_{H}}{\mu}=\frac{v D_{H}}{v}=\frac{\mathrm{QD}_{\mathrm{H}}}{v \mathrm{~A}}
$$

Where:

$\mathrm{D}_{\mathrm{H}}=$ The hydraulic diameter of the pipe; its characteristic travelled length, L (m)

$\mathrm{Q}=$ The volumetric flow rate $\left(\mathrm{m}^{3} / \mathrm{s}\right)$

$\mathrm{A}=$ The pipe cross-sectional area $\left(\mathrm{m}^{2}\right)$

Vis $=$ The mean velocity of the fluid (SI units: $\mathrm{m} / \mathrm{s}$ )

$\mu$ is $=$ The dynamic viscosity of the fluid $\left(\mathrm{Pa} \cdot \mathrm{s}\right.$ or $\mathrm{N} \cdot \mathrm{s} / \mathrm{m}^{2}$ or $\mathrm{kg} /(\mathrm{m} \cdot \mathrm{s}))$

vis $=$ The kinematic viscosity $(\mathrm{v}=\mu / \mathrm{p})\left(\mathrm{m}^{2} / \mathrm{s}\right)$

pis $=$ The density of the fluid $\left(\mathrm{kg} / \mathrm{m}^{3}\right)$

\subsection{Shell-Side Heat Transfer Coefficient}

The heat resistances in the shell-side consist of those of the condensate film and the cooling of the sensible heat of the flue gases. For the heat transfer coefficient of gas stream $\left(\mathrm{h}_{\mathrm{g}}\right)$ in the shell-side, the following correlation can be used Equation 4 (Chen et al., 2012):

$\mathrm{Nu}_{\mathrm{s} . \mathrm{g}}=\frac{\mathrm{h}_{\mathrm{g}} \mathrm{D}_{\mathrm{e}}}{\lambda_{\mathrm{g}}}=0.27 \mathrm{Re}_{\mathrm{De}}^{0.63} \operatorname{Pr}_{\mathrm{g}}^{0.34}$

Where:

$\lambda_{\mathrm{g}}=$ The thermal conductivity of gas mixture

$\mathrm{D}_{\mathrm{e}}=$ The equivalent diameter calculated along (instead of across) the long axes of the shell

The compositions of exhaust gas from combined cycle are non-condensable and the steam concentration is small. Thus, the heat transfer process in the shell and tube heat exchanger for flue gas is forced convective heat transfer with partial water vapour condensation. The condensation-convection heat transfer coefficient and sensible heat transfer coefficient is of the same order. As the flue gas flows downward in the channel, when the wall temperature $T_{w}$ is lower than the saturation temperature $T_{s}$ of the vapour, the temperature of flue gas next to wall is below $T_{s}$ and then condensation will take place on the wall surface and a condensate film forms (Shi et al., 2011). The local overall heat transfer coefficient (U) from the shell-side to the tube-side can be show as Equation 5 (Chen et al., 2012):

$1 / \mathrm{U}=1 / \mathrm{h}_{\mathrm{t}}+\mathrm{R}+1 / \mathrm{h}_{\mathrm{s}, \mathrm{ef}}$

Where: 
$\mathrm{R}=$ The thermal resistance due to the tube wall and fouling

$\mathrm{h}_{\mathrm{sef}}=$ An effective shell-side heat transfer coefficient

The condensation occurs, this effective coefficient is obtained by Equation 6:

$$
1 / \mathrm{h}_{\mathrm{s}, \mathrm{ef}}=1 / \mathrm{h}_{\mathrm{m}, \mathrm{N}}+\mathrm{q}_{\mathrm{g}} / \mathrm{q} / \mathrm{h}_{\mathrm{g}}
$$

Where:

$\mathrm{Q}=$ The total heat flux from the shell-side to the tube-side

$\mathrm{Q}_{\mathrm{g}}=$ The sensible heat flux from the non-condensable gas components

Fouling and thermal resistance of tube wall are certain that fouling may occur inside and/or outside the tubes in the condensing boiler. Although fouling is time dependent, only a fixed value can be assumed during the design stage. Inside the tubes, the feed water to the bolier should be chemically treated. However, outside the tubes, the flue gas contains ultrafine particles and trace acid gases. Therefore the condensate on the shell-side may contain some amounts of solid and liquid contaminants. Consequently, the fouling resistances inside and outside the tubes $\left(R_{f, I}\right.$ and $\left.R_{f, o}\right)$ were chosen as $0.000176 \mathrm{~m}^{2} \mathrm{~K} / \mathrm{W}$ and $0.00176 \mathrm{~m}^{2} \mathrm{~K} / \mathrm{W}$. The thermal resistance of the stainless steel wall is $6.55 \times 10^{-5} \mathrm{~m}^{2} \mathrm{~K} / \mathrm{W}$ whereas for the carbon steel tubes coated with polypropylene, the thermal resistance is approximately $9.23 \times 10^{-4}$ due to the low thermal conductivity of polypropylene.

Many possibilities' of energy saving systems in textile finishing are as follows: (i) waste water heat recovery; (ii) condensing stack economizer; (iii) wood gasification; (iv) conventional or wood gasification cogeneration of electricity and steam; (v) wood gas for coater frame incineration; (vi) air to air heat recovery; and (vii) electrical saving. All seven areas apply to dyehouses in the category, which is spending up to 750,000 annually on boiler fuel (Pulat et al., 2009).

This research focuses on the utilization of waste heat boiler to heat exchanger for preheat palm oil shell which the utilization of waste heat of flue gases is one of the beat possibilities for reduction of the green house gases emissions. This study aims to achieving the following: (i) calculation of the shell and tube heat exchanger for waste heat boiler in dyeing process, (ii) analysis of model solution heat exchanger is performed by ANSYS, (iii) economic evaluation of heat exchanger.

\section{MATERIALS AND METHODS}

\subsection{Materials}

Gas to gas waste-heat recovery exchangers may be categorized as plate-fin and primary surface exchangers, heat pipe exchangers, rotary regenerators, radiation and convection recuperator and runaround coils. Metallic radiation recuperators consist of two concentric metal tubes with the hot exhaust (flue) gas flowing through the central duct and the air to be preheated flowing in the outer annulus (Pulat et al., 2009), using as exhaust gas from boiler in textile industry (Y.R.C. Textile. Co, LTD.,Thailand).

\subsection{Experimental investigation}

The design of these heat exchangers is usually carried out with the aid of ANSYS using either commercial software packages available at the market or in house software products. Modeling unambiguously belongs to methods for an improved or even optimum design of heat exchangers. In this research are following areas: (i) simulation based on energy and mass balance which is thermal and hydraulic calculation of heat exchangers and (ii) economics evaluation.

Simulation based on energy and mass balance is the first step in calculations is necessary for evaluation of all process parameters for further calculation of heat exchangers (values of process fluids temperature, flow rates and properties of exhaust gas and air. For simulation several well-known commercial software packages are used like e.g., ASPEN PLUS, ChemCAD, Pro II, HYSYS (Stehlik, 2011), however, for some special areas like thermal processing of waste including energy utilization a creation of own software packages proved itself to be good solution. There are using specific software ANSYS which is suitable to gas-to-gas waste-heat recovery exchangers.

Values of process: the temperatures of exhaust gas and air inlet are average 190 and $34^{\circ} \mathrm{C}$, respectively as shown in Fig. 2 and 3.

The flow rate of exhaust gas from boiler and air are average about 6.2 and $2.84 \mathrm{~kg} \mathrm{sec}^{-1}$, respectively as shown in Fig. 4 and 5.

The chemical composition of exhaust gas consisted of the following percentage by weight; $\mathrm{N}_{2}, 69.712 \%$; $\mathrm{O}_{2}, 4.274 \% ; \quad \mathrm{CO}_{2}, \quad 13.629 \% ; \quad \mathrm{SO}_{2}, \quad 0.02 \% ; \quad \mathrm{H}_{2} \mathrm{O}$, $12.382 \%$. The moisture content of air is average about $0.2 \mathrm{~kg}$ vapor $/ \mathrm{kg}$ dry air. 


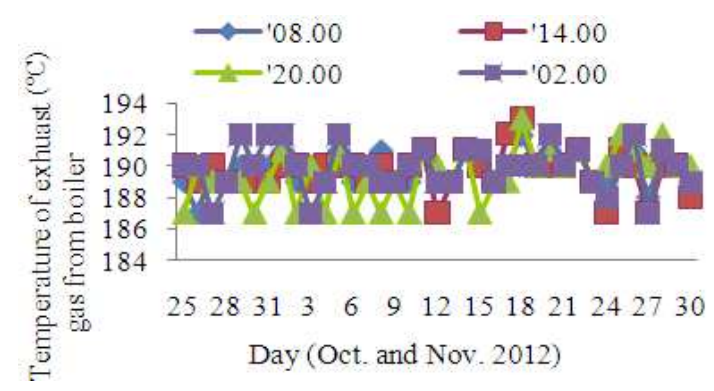

Fig. 2. The measure of exhaust gas temperature from boiler between 25 Oct to 30 Nov 2012 on 8.00, 14.00, 20.00 and $02.00 \mathrm{am}$

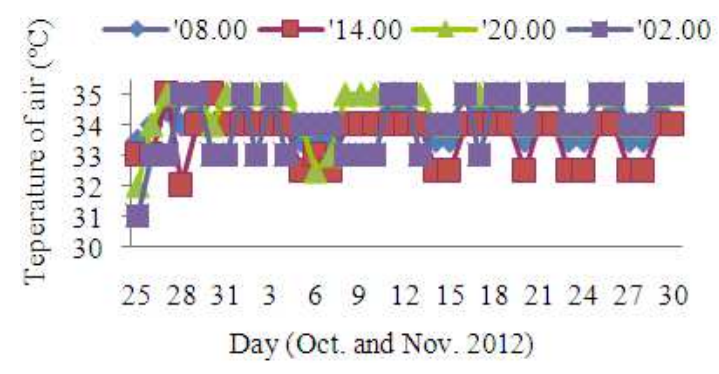

Fig. 3. The measure of air temperature between 25 Oct. to 30 Nov. 2012 on $8.00,14.00,20.00$ and 02.00 am

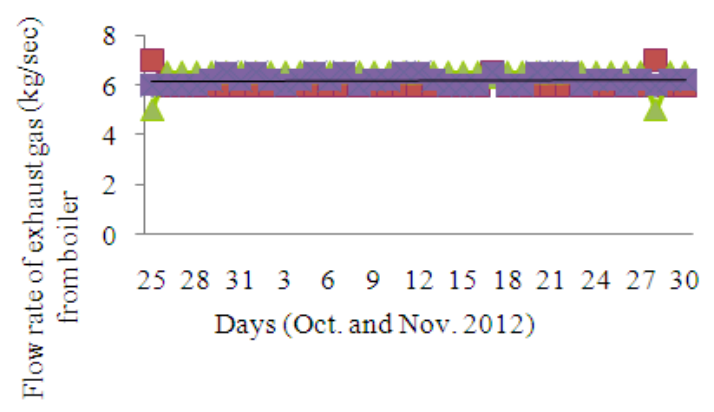

Fig. 4. The flow rate of exhaust gas from boiler between 25 Oct. to 30 Nov. 2012 on $8.00,14.00,20.00$ and 02.00 am

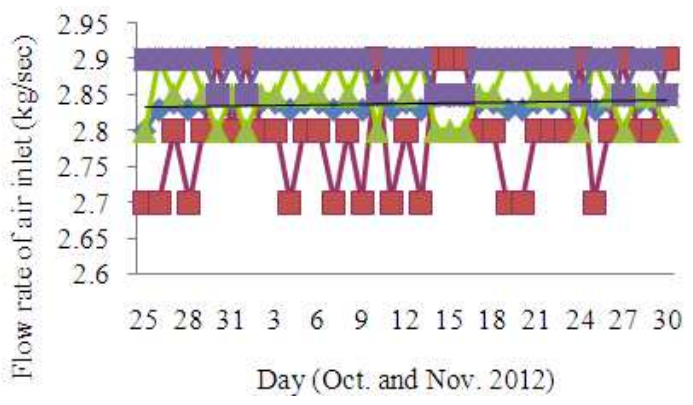

Fig. 5. The flow rate of air between 25 Oct. to 30 Nov. 2012 on $8.00,14.00,20.00$ and $02.00 \mathrm{am}$
Economic evaluation is computation of Payback Period (PBP). The Payback Period (PBP) is the length of time that it takes for a project to recoup its initial cost out of the cash receipts that it generates. This period is sometimes referred to as" the time that it takes for an investment to pay for itself". The basic premise of the payback method is that the more quickly the cost of an investment can be recovered, the more desirable is the investment. The payback period is expressed in years. When the net annual cash inflow is the same every year, the following formula can be used to calculate the payback period:

$$
\mathrm{PBP}=\text { Investment cost/Net annual cash inflow }
$$

\section{RESULTS}

\subsection{Selection of Heat Exchanger}

In the present work s shell and tube heat exchanger is selected to extract heat from the exhaust gas to air, in general the surface convective heat transfer surface on the gas side needs to have a much larger area for better heat transfer. Hence a separate heat exchanger is designed with tubes in which the exhaust gas is allowed to pass through the shell side to achieve higher surface area on the gas side. The major criterion in the design of waste heat recovery system is the proper selection of heat exchanger with optimum conditions. In the present investigation, the initial data are consist of palm shell consumption 70 ton day $^{-1}$ (feed to boiler $0.8102 \mathrm{~kg} \mathrm{sec}^{-1}$ ), $24 \%$ of initial moisture content of palm shell, $0.1944 \mathrm{~kg} \mathrm{H}_{2} \mathrm{O} / \mathrm{s}$ of initial moisture flow rate in palm shell, $0.6157 \mathrm{~kg} \mathrm{sec}^{-1}$ of born dry palm shell mass, $15 \%$ palm shell moisture content requirement, $0.7244 \mathrm{~kg} \mathrm{sec}^{-1}$ of outlet palm shell weight, $0.1087 \mathrm{~kg} \mathrm{H} \mathrm{H}_{2} \mathrm{O} / \mathrm{s}$ of outlet moisture flow rate in palm shell and $0.0858 \mathrm{~kg} \mathrm{H}_{2} \mathrm{O} / \mathrm{s}$ of drying load.

The results of input and output data for shell and tube heat exchanger by using ANSYS software are reported in Fig. 6 and Table 1. The air is used to simulate the exhaust gas from boiler. The heat exchanger used for experiments is a shell and tube construction in a staggered arrangement as shown in Fig. 6. The tubes are mechanically expanded for the purposes of assembling with shell. The heat exchanger is in cross-counter flow. The air is circulated in four passes from the top to the bottom of the test section, in overall counter-flow with exhaust gas.

The front area is $1720 \times 1720 \mathrm{~mm}$, the flow length $7500 \mathrm{~mm}$, the inner and outer diameter of exhaust gas is $800 \mathrm{~mm}$, the tube assembly consist of 196 tubes, the tube diameter is $76.2 \mathrm{~mm}$, the tube thickness is $2.6 \mathrm{~mm}$, the tube length is $4500 \mathrm{~mm}$ and the tube length of air inner and air outer is $500 \mathrm{~mm}$ as shown in (Fig. 7). 
Prateep Pattanapunt et al. / American Journal of Environmental Science 9 (3): 231-239, 2013

1720

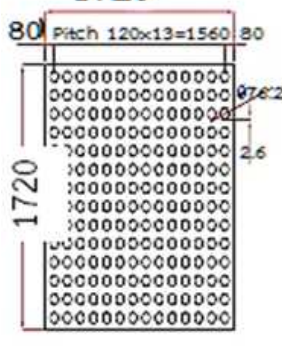

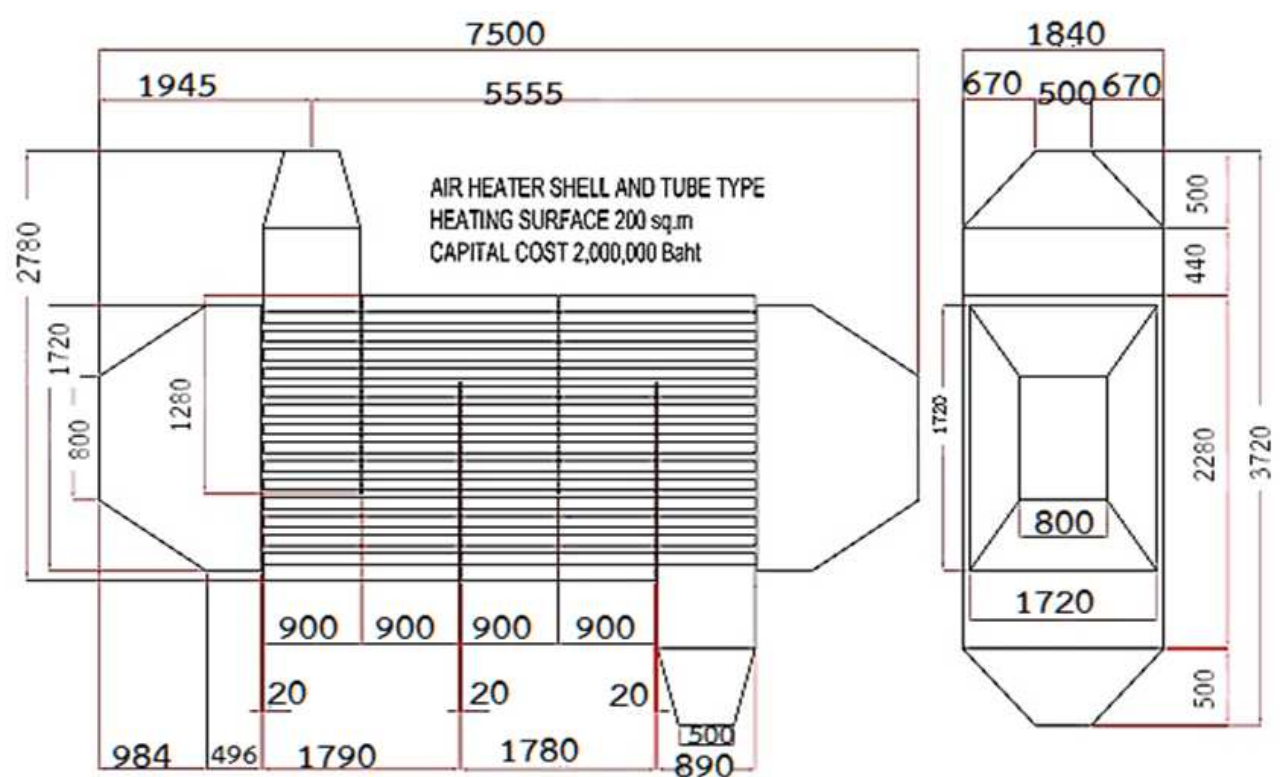

Fig. 6. The flow rate of air between 25 Oct. to 30 Nov. 2012 on $8.00,14.00,20.00$ and 02.00 am

Flue gas from boiler

1. Mass flow rate

2. Temperature $190^{\circ} \mathrm{C}$

3 . Velocity $12.3 \mathrm{~m} \mathrm{sec}^{-1}$

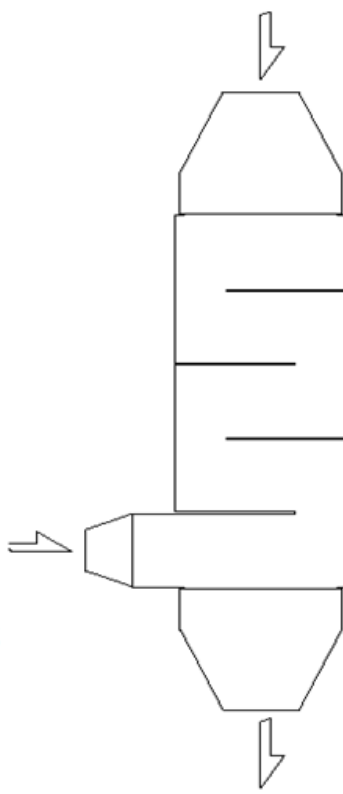

Flues gas from boiler

1. Mass flow rate $8.2 \mathrm{~kg} \mathrm{sec}^{-1}$

2. Temperature $160^{\circ} \mathrm{C}$

3. Pressure drop in tube $410 \mathrm{pa}$
Hot air

1. Mass flow rate $2.84 \mathrm{~kg} \mathrm{sec}^{-1}$

2. Temperature $85^{\circ} \mathrm{C}$

3. Initial moisture content $0.02 \mathrm{~kg} \mathrm{H} 2 \mathrm{O} / \mathrm{kg}$-dry air 4. Pressure drop in shell $2580 \mathrm{pa}$<smiles>C1=CC=C1</smiles>

70 ton day $^{-1}$ Palm shell dryer<smiles>C1=CC12CC2</smiles>

Wet air

1. Mass flow rate $2.9 \mathrm{~kg} \mathrm{sec}^{-1}$

2. Temperature $38^{\circ} \mathrm{C}$

3 . Outlet moisture content $0.044 \mathrm{~kg} \mathrm{H} 2 \mathrm{O} / \mathrm{kg}$

Normal air

2. Temperature $34^{\circ} \mathrm{C}$

Velocity $9.92 \mathrm{~m} \mathrm{sec}^{-1}$

4. Initial moisture content $0.02 \mathrm{~kg}$ $\mathrm{H} 2 \mathrm{O} / \mathrm{kg}$-dry air

Fig. 7. Geometric dimensions of the shell and tube heat exchanger 


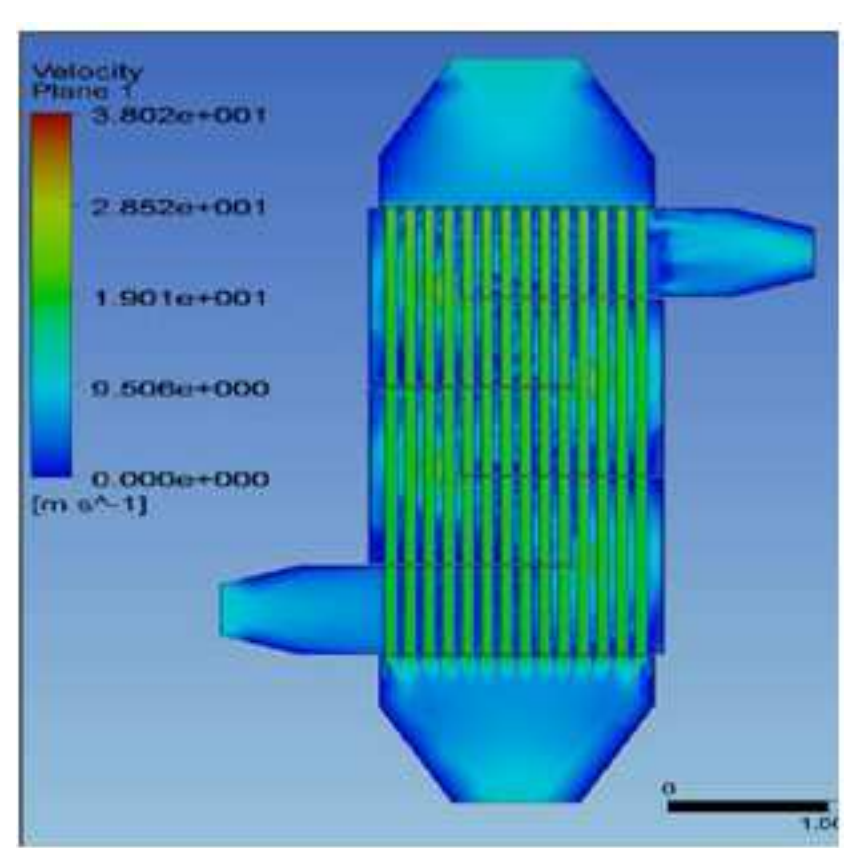

(a)
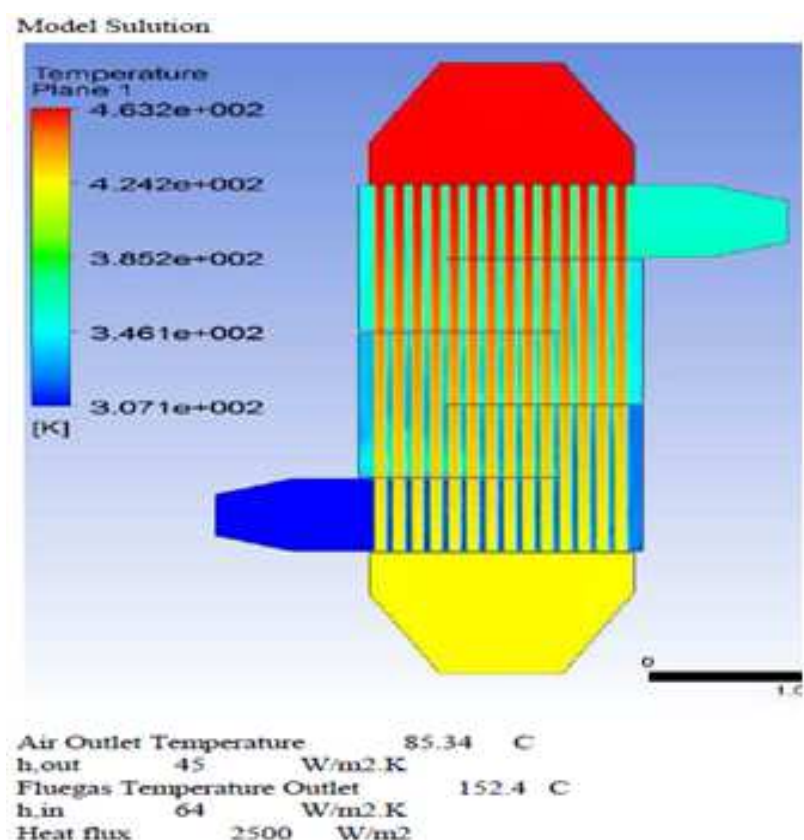

(b)

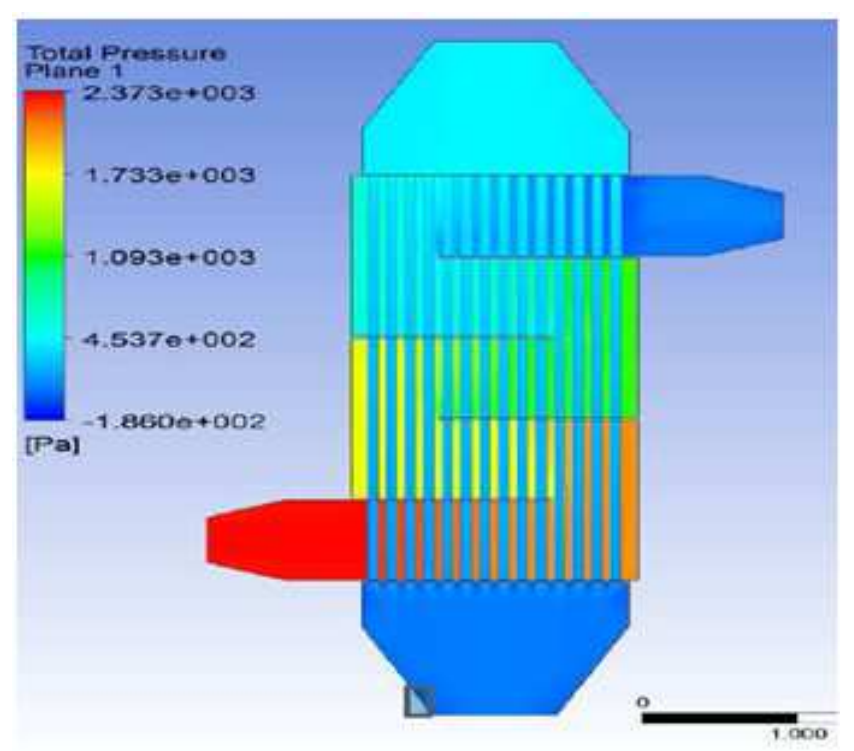

(c)

Fig. 8. (a) Geometry of velocity with heat exchanger, (b) Geometry of temperature with heat exchanger and (c) Geometry of total pressure with heat exchanger

The results of simulation from ANSYS are shown reported in Table 1. The flow rate inlet and outlet is measured using a $\mathrm{V}$-cone flow meter. The air inlet and outlet temperature are measured using two T-type thermocouple meshes placed upstream and downstream of test section. The core pressure drop across the heat exchanger is measured using eight pressure taps (four upstream and four down stream). The test conditions are as follows: Facing air velocity at the inlet and outlet of test section is $9.506 \mathrm{~m} \mathrm{sec}^{-1}$ (Fig. 8a). 
Table 1. The parameter input and output of heat exchanger design Parameter Input and output

\begin{tabular}{|c|c|c|}
\hline \multirow[b]{2}{*}{ Input data } & \\
\hline & Calculation formula & Calculation result \\
\hline Number unit & Description & Number unit \\
\hline $2920 \mathrm{~kg} \mathrm{~h}^{-1}$ & $\begin{array}{l}\text { Q: Fuel } \\
\text { consumption }\end{array}$ & $2920 \mathrm{~kg} \mathrm{~h}^{-1}$ \\
\hline 0.35 & $\begin{array}{l}\text { F: Heat transfer } \\
\text { factor }\end{array}$ & 0.35 \\
\hline $211.14 \mathrm{~m}^{2}$ & Hs: Heating surface & $211.14 \mathrm{~m}^{2}$ \\
\hline $0.0762 \mathrm{~m}$ & $\begin{array}{l}\text { d: Tube air heater } \\
\text { diameter }\end{array}$ & $0.0762 \mathrm{~m}$ \\
\hline $4.5 \mathrm{~m}$ & $\begin{array}{l}\text { L: Tube air heater } \\
\text { length }\end{array}$ & $4.5 \mathrm{~m}$ \\
\hline 196pcs. & $\begin{array}{l}\text { Q'tyL: Tube air } \\
\text { heater number }\end{array}$ & 196 pes. \\
\hline $0.0026 \mathrm{~m}$ & $\begin{array}{l}\text { Ts: Thickness of } \\
\text { tube wall }\end{array}$ & $0.0026 \mathrm{~m}$ \\
\hline 1 & $\begin{array}{l}\text { F: Tube air heating } \\
\text { factor surface }\end{array}$ & 1 \\
\hline $190^{\circ} \mathrm{C}$ & $\begin{array}{l}\text { Tg1: Flue gas } \\
\text { temperature } \\
\text { after hot oil boiler }\end{array}$ & $190^{\circ} \mathrm{C}$ \\
\hline $166.05^{\circ} \mathrm{C}$ & $\begin{array}{l}\text { Tg2: Flue gas } \\
\text { temperature } \\
\text { after air heater }\end{array}$ & $166.05^{\circ} \mathrm{C}$ \\
\hline $34^{\circ} \mathrm{C}$ & $\begin{array}{l}\text { Ta1: Open air } \\
\text { temperature }\end{array}$ & $34^{\circ} \mathrm{C}$ \\
\hline $89.4^{\circ} \mathrm{C}$ & $\begin{array}{l}\text { Ta2: Hot air } \\
\text { temperature }\end{array}$ & $89.4^{\circ} \mathrm{C}$ \\
\hline $120 \mathrm{~mm}$ & $\begin{array}{l}\text { Pitch: Tube air } \\
\text { heater pitch }\end{array}$ & $120 \mathrm{~mm}$ \\
\hline $0.31815 \mathrm{~m}^{2}$ & $\begin{array}{l}\text { Pa: Pass area } \\
\text { in minimum section }\end{array}$ & 0.31815 \\
\hline
\end{tabular}

Table 2. First investment for shell and tube heat exchanger

\begin{tabular}{ll}
\hline Investment item & Cost (THB) \\
\hline Land and building & \\
Machine/equipment & 200,000 \\
$2,356,530.50$ & \\
Total first investment & $2,556,530.50$ \\
\hline
\end{tabular}

Table 3. Operating cost for shell and tube heat exchanger

\begin{tabular}{ll}
\hline Operating cost & (THB/year) \\
\hline Labors (3 workers/shifts) & 97,200 \\
Maintenance (15\% of machine cost) & 50,000 \\
Electricity & 792,824 \\
Operated cost & $550,581.20$ \\
Total & $1,490,605.2$ \\
\hline
\end{tabular}

The inlet temperature of exhaust gas is $190^{\circ} \mathrm{C}$, which is the exhaust gas outlet temperature is $152.2^{\circ} \mathrm{C}$. While the inlet temperature of air is $34^{\circ} \mathrm{C}$, which is the outlet temperature is $85.34^{\circ} \mathrm{C}$ (Fig. $\left.8 \mathbf{b}\right)$.
The total pressure of exhaust gas at the inlet is 0.4537 $\mathrm{kPa}$, which is the outlet about $0.186 \mathrm{kPa}$. The total pressure of air at the inlet is $2.373 \mathrm{kPa}$, which is the outlet about $0.186 \mathrm{kPa}$ (Fig. 8c).

\subsection{Economic Evaluation}

In economic analysis for investment is shell and tube heat exchanger with capacity 70 tons/day, using palm shell to boiler from the case study. It is assumed that, the fifteen years of project life, working time at 8 hours a day, 360 days a year, direct labor cost per day is 300 $\mathrm{THB} /$ worker, the interest rate of $6.5 \%$, electricity cost of $2.97 \mathrm{THB} / \mathrm{kWh}$, the palm shell is 3,000 THB/tonne and maintenance cost is $15 \%$ of the machines' prices. The first investment is 2.907 million THB. Income from this case is the save energy cost to boiler about 6.6 million $\mathrm{THB} /$ year. Amount of electricity used for fan is 30 $\mathrm{kW} /$ hours. The approximated first investment and operating cost are shown in Table 2 and 3.

Results from the analysis show that, payback period of the heat exchanger are approximate 6 mouths; the Internal Rate of Return (IRR) is $182 \%$.

\section{DISCUSSION}

The principal reason for attempting to recover waste heat is economic. All waste heat that is successfully recovered directly substitutes for purchased energy and therefore reduces the consumption of and the cost of that energy. A second potential benefit is realized when waste-heat substitution results in smaller capacity requirements for energy conversion equipment. Therefore, the use of waste-heat recovery can reduce the requirement for space-heating energy. This permits a reduction in the capacity of furnaces or boilers used for heating the plant. In every case of waste-heat recovery, a gratuitous benefit is derived: That of reducing thermal pollution of the environment by an amount exactly equal to the energy recovered, at no direct cost to the recover (Pulat et al., 2009).

Experimental results indicate the suitability of the shell and tube heat exchanger in textile industry, especially on boiler in dyeing process. Energy and environmental studied show that in increase of process efficiency simultaneously with a decrease of thermal pollution. In this study, system parameters such as heat capacity, recuperator energy saving potential were calculated. If feed air is heated with flue gases, the fuel consumption is reduced by about $2.05 \%(322.72 \mathrm{Kj}$ $\mathrm{kg}^{-1}$ ), while the shell and tube heat exchanger outlet flue gases temperature decreases from 190 to $150^{\circ} \mathrm{C}$. 


\section{CONCLUSION}

The present investigation has demonstrated that waste heat recovery exhaust flue gas from boiler to shell and tube heat exchanger for drying palm shell before input to boiler and ANSYS program of 70 tons/day were design. The second law of thermodynamic is powerful tool for design, optimization and performance evaluation of thermals systems. Base on the present analysis, the following results were concluded: (i) The heat exchanger is in cross-counter flow. The air is circulated in four passes from the top to the bottom of the test section, in overall counter-flow with exhaust gas. The front area is $1720 \times 1720 \mathrm{~mm}$, the flow length $7500 \mathrm{~mm}$, the inner and outer diameter of exhaust gas is $800 \mathrm{~mm}$, the tube assembly consist of 196 tubes, the tube diameter is $76.2 \mathrm{~mm}$, the tube thickness is 2.6 $\mathrm{mm}$, the tube length is $4500 \mathrm{~mm}$ and the tube length of air inner and air outer is $500 \mathrm{~mm}$. (ii) The maximum heat extracted using the heat exchanger at full load condition is around $2920 \mathrm{~kg} \mathrm{~h}^{-1}$. By decreasing the exhaust gas temperature about $150^{\circ} \mathrm{C}$. it is possible to recover the heat, which is liberated from fuel along with the air. (iii) The result show that, the boiler for superheated type there are exhaust gas temperature is $190^{\circ} \mathrm{C}, 24 \%$ the moisture content of fuel and there are palm shell 70 tons/day which there are the high temperature after the heat exchanger, $150^{\circ} \mathrm{C}$. It was occurred acid rain. The hot air from heat exchanger process can be reduced the moisture of palm shell fuel to $15 \%$. (iv) The results of the thermoeconomical analysis were given for both academic and industrial users. Also optimum parameters presented here are simple and have wide applicability. The payback period was determined about 6 months for investigated ANSYS.

Therefore, it can be concluded that waste-heat recovery techniques, which are environmental friendly and have technical and economical advantageous, should be evaluated in order to contribute to energy economy studies in Thailand.

\section{ACKNOWLEDGMENTS}

The researchers thank Y.R.C. Textile. Co, LTD., Thailand, for providing the ANSYS simulation and Rattanakosin College for Sustainable Energy and Environmemt, Rajamangala University of Technology
Rattanakosin96 moo 3 Puthanomthon Sai 5, Salaya, Puthamonthon Nakhon Pathom, 73170 Thailand, for the help rendered during manuscript preparation.

\section{REFERENCES}

Chaojun, W., B. He, S. Sun, Y. Wu and N. Yan et al., 2012. Application of a low pressure economizer for waste heat recovery from the exhaust flue gas in a $600 \mathrm{MW}$ power plant. Energy, 48: 196-202. DOI: 10.1016/j.energy.2012.01.045

Chen, Q., K. Finney, H. Li, X. Zhang and J. Zhou et al., 2012. Condensing boiler applications in the process industry. Applied Energy, 89: 30-36. DOI: 10.1016/j.apenergy.2010.11.020

Hasanbeigi, A. and L. Price, 2012. A review of energy use and energy efficiency technologies for the textile industry. Renew. Sustain. Energy Rev., 16: 36483665. DOI: 10.1016/j.rser.2012.03.029

Pandiyarajan, V., M.C. Pandian, E. Malan, R. Velraj and R.V. Seeniraj, 2011. Experimental investigation on heat recovery from diesel engine exhaust using finned shell and tube heat exchanger and thermal storage system. Appli. Energy, 88: 77-87. DOI: 10.1016/j.apenergy.2010.07.023

Pulat, E., A.B. Etemoglu and M. Can, 2009. Waste-Heat recovery potential in turkish textile industry: Case study for city of bursa. Renew. Sustain. Energy Rev., 13: 663-672. DOI: 10.1016/j.rser.2007.10.002

Shi, X., D. Che, B. Angew and J. Gao, 2011. An investigation of the performance of compact heat exchanger for latent heat recovery from exhaust flue gases. Int. J. Heat Mass Trans., 54: 606-615. DOI: 10.1016/j.ijheatmasstransfer.2010.09.009

Stehlik, P., 2011. Conventional versus specific types of heat exchangers in the case of polluted flue gas as the process fluid-a review. Applied Thermal Eng., 31: 1-13. DOI: 10.1016/j.applthermaleng.2010.06.013

Zabaniotou, A. and K. Andreou, 2010. Development of alternative energy sources for GHG emissions reduction in the textile industry by energy recovery from cotton ginning waste. J. Cleaner Product., 18: 784-790. DOI: 10.1016/j.jclepro.2010.01.006 